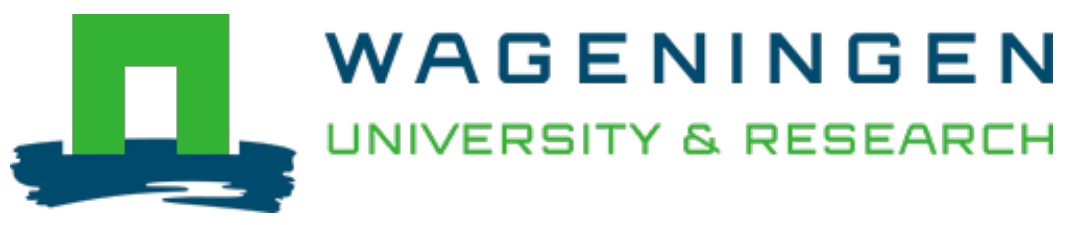

\author{
Salinity drives growth dynamics of the mangrove tree Sonneratia apetala Buch. - \\ Ham. in the Sundarbans, Bangladesh \\ Dendrochronologia \\ Rahman, Md Saidur; Sass-Klaassen, Ute; Zuidema, Pieter A.; Chowdhury, Md Qumruzzaman; Beeckman, \\ Hans \\ https://doi.org/10.1016/j.dendro.2020.125711
}

This publication is made publicly available in the institutional repository of Wageningen University and Research, under the terms of article $25 \mathrm{fa}$ of the Dutch Copyright Act, also known as the Amendment Taverne. This has been done with explicit consent by the author.

Article 25 fa states that the author of a short scientific work funded either wholly or partially by Dutch public funds is entitled to make that work publicly available for no consideration following a reasonable period of time after the work was first published, provided that clear reference is made to the source of the first publication of the work.

This publication is distributed under The Association of Universities in the Netherlands (VSNU) 'Article $25 \mathrm{fa}$ implementation' project. In this project research outputs of researchers employed by Dutch Universities that comply with the legal requirements of Article 25fa of the Dutch Copyright Act are distributed online and free of cost or other barriers in institutional repositories. Research outputs are distributed six months after their first online publication in the original published version and with proper attribution to the source of the original publication.

You are permitted to download and use the publication for personal purposes. All rights remain with the author(s) and / or copyright owner(s) of this work. Any use of the publication or parts of it other than authorised under article $25 \mathrm{fa}$ of the Dutch Copyright act is prohibited. Wageningen University \& Research and the author(s) of this publication shall not be held responsible or liable for any damages resulting from your (re)use of this publication.

For questions regarding the public availability of this publication please contact openscience.library@wur.nl 
ORIGINAL ARTICLE

\title{
Salinity drives growth dynamics of the mangrove tree Sonneratia apetala Buch. -Ham. in the Sundarbans, Bangladesh
}

\author{
Md. Saidur Rahman ${ }^{\mathrm{a}, \mathrm{b}, *}$, Ute Sass-Klaassen ${ }^{\mathrm{a}}$, Pieter A. Zuidema ${ }^{\mathrm{a}}$, \\ Md. Qumruzzaman Chowdhury, ${ }^{\mathrm{c}, \mathrm{d}}$, Hans Beeckman ${ }^{\mathrm{c}}$ \\ ${ }^{a}$ Forest Ecology and Forest Management Group, Wageningen University and Research, P.O. Box 47, 6700 AA Wageningen, The Netherlands \\ ${ }^{\mathrm{b}}$ Forestry and Wood Technology Discipline, Khulna University, Khulna-9208, Bangladesh \\ ${ }^{\mathrm{c}}$ Wood Biology Service, Royal Museum for Central Africa (RMCA), Leuvensesteenweg 13, Tervuren, Belgium \\ ${ }^{\mathrm{d}}$ Department of Forestry and Environmental Science, Shahjalal University of Science and Technology, Sylhet-3114, Bangladesh
}

\section{A R T I C L E I N F O}

\section{Keywords:}

Cambial activity

Dendrochronology

Growth ring

Sonneratia apetala

The Sundarbans

\begin{abstract}
A B S T R A C T
Mangroves throughout the world are threatened by environmental changes apart from anthropogenic disturbances. Many of these changes may inhibit the growth and survival of mangrove species. To understand and predict the effects of global change on mangrove forests, it is necessary to obtain insights on the growth dynamics of mangroves in relation to environmental factors. This study was conducted on Sonneratia apetala, a mangrove species which grows under a range of salinity conditions across the Sundarbans in Bangladesh. We studied trees growing under respectively high, medium, and low salinity conditions based on the influence of freshwater discharge. First, the periodicity of radial growth across the year was detected by applying cambial analyses. Based on tree-ring analyses, we calculated the growth response of $S$. apetala to monthly variation in precipitation and temperature as well as river discharge, as a proxy for salinity. We found the cambium of $S$. apetala being active during the monsoon and post-monsoon period whereas it was dormant in the pre-monsoon. This periodicity in radial growth leads to the formation of distinct annual rings with ring boundaries being marked by radially flattened fibres. $S$. apetala trees growing under low salinity conditions generally show higher growth rates indicating the positive impact of river discharge, i.e. freshwater input on mangrove growth. Wet and warm conditions during the monsoon period positively affected $S$. apetala growth, especially in the low salinity zone. Our results show that salinity is the primary driver of growth dynamics of $S$. apetala in the Sundarbans. A gradual or seasonal increase in salinity, e.g. as a consequence of sea-level rise may therefore importantly alter the growth of this species, possibly leading to changes in mangrove forest dynamics and zonation.
\end{abstract}

\section{Introduction}

Mangrove forests are the most productive ecosystems across the globe (Woodroffe, 1982; Donato et al., 2011), and play an essential socio-economic as well as ecological role by providing a plethora of ecosystem services and products (Dahdouh-Guebas et al., 2000; Dahdouh-Guebas and Koedam, 2008; Himes-Cornell et al., 2018; Islam et al., 2018a). The Sundarbans, the largest continuous natural mangrove forest in the world, is located on the coast of Bay of Bengal (the estuary of the Ganges-Brahmaputra rivers) in Bangladesh $\left(6,014 \mathrm{~km}^{2}\right)$ and India $\left(4,000 \mathrm{~km}^{2}\right.$ ) (Chaudhuri and Choudhury, 1994). A portion of Bangladesh Sundarbans has been declared a Ramsar site under the Ramsar Convention in 1992 and UNESCO declared as a World Heritage
Site for its unique conservation value in 1997 (Siddiqi, 2001; Sarker et al., 2019). Historically, the anthropogenic disturbances, such as overexploitation, shrimp and salt farming, oil spills, diseases, biological invasion, and natural calamities have been declining this ecosystem leading to diminishing growing stock (Iftekhar and Saenger, 2008). Besides, the Sundarbans has been experiencing a sea-level rise, and climate and environmental changes from the last century (McLeod and Salm, 2006; Gilman et al., 2008; Alongi, 2015). Based on the recent IPCC forecasts, this forest is under threat with the projected mean sealevel rise to $0.98 \mathrm{~m}$ in 2100 , whereas the average elevation is $2 \mathrm{~m}$ (Church et al., 2013; Collins et al., 2013). It is a sea-dominated mangrove where precipitation and up-stream freshwater river flows used to modulate salinity and keep the ecosystem favourable for trees

\footnotetext{
* Corresponding author.

E-mail address: msrahman@fwt.ku.ac.bd (Md. S. Rahman).
} 


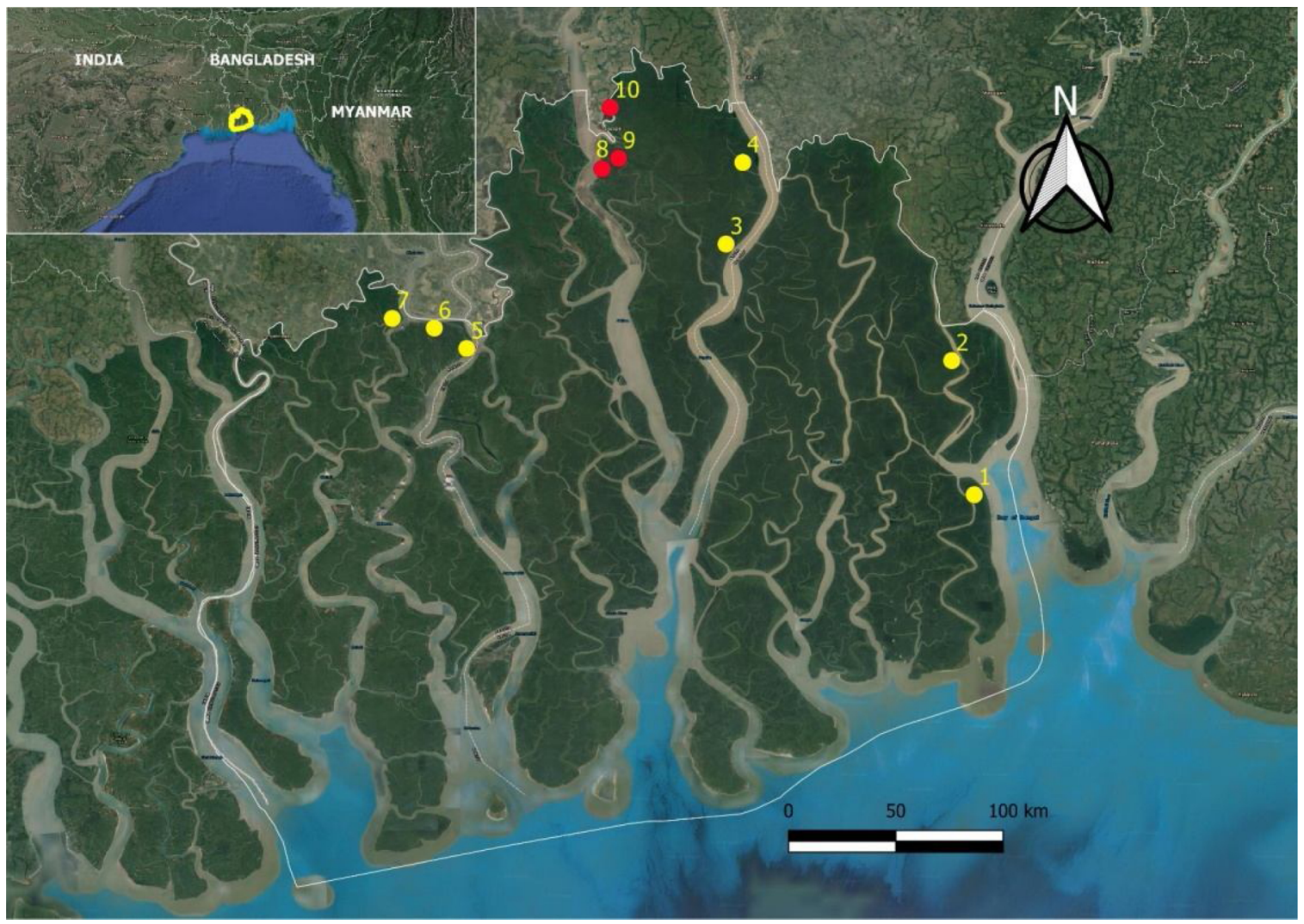

Fig. 1. Sampling locations in the Sundarbans. Yellow circle (1-7) denotes locations for the collection of stem disc for developing chronology, and red circle (8-10) indicates sampling sites for cambium studies. Locations 1 and 2 represent Low salinity zone (LSZ), 3, 4 and 8-10 represent Medium salinity zone (MSZ), and 5-7 symbolises for High salinity zone (HSZ).

(Chowdhury et al., 2016a; Sarker et al., 2019). Given the importance of the retrospective understanding of the growth dynamics of trees in natural forests in response to environmental changes, tree-ring research has proved to be a valuable tool. Besides tree age, it enables to detect growth-limiting factors for various tree species and through the calculation of climate-growth relationships enables to predict impacts of climate change on growth dynamics of mangroves (Menezes et al., 2003; Verheyden et al., 2004; Robert et al., 2011; Chowdhury et al., 2016b).

The application of tree-ring research is often limited in the tropics due to the complex anatomy of growth rings (Worbes et al., 2003; Rozendaal and Zuidema, 2010; Pumijumnong, 2013; Gebrekirstos et al., 2014; Groenendijk et al., 2014; Gaspard et al., 2018; Islam et al., $2018 \mathrm{~b})$ and lack of knowledge on the seasonality of growth-ring formation (e.g. Lisi et al., 2008; Morel et al., 2015). Mangrove species have received less attention due to absent or indistinct ring boundaries in many species (Amobi, 1974; Srivastava and Suzuki, 2001; Rozendaal and Zuidema, 2010; Robert et al., 2011). However, several studies confirmed the presence of annual growth rings in Rhizophora mangle, $R$. mucronata, Sonneratia apetala, S. alba, Heritiera fomes, H. littoralis, Xylocarpus granatum and Lumnitzera racemosa (Menezes et al., 2003; Verheyden et al., 2004; Chowdhury et al., 2008, 2016a, b; Robert et al., 2011). For many mangrove species, the timing of growth ring formation is not known which limits chances for the exact dating of ring-width series and hinders the analyses of driving environmental factors behind tree growth (Menezes et al., 2003; Verheyden et al., 2004). Studies on seasonal wood formation are essential to prove the presence of annual growth rings and allow for correct estimation of tree biomass formation (Mbow et al., 2013; Köhl et al., 2017), but also to understand the physiological background of calculated climate-growth relationships (Schöngart et al., 2006; Chowdhury et al., 2016a; Rahman et al., 2017; Martinez del Castillo et al., 2018), for predictions of tree growth under future environmental change scenario's (Brienen et al., 2010; Huang et al., 2013; Wagner et al., 2014).

Growth rings are produced due to alternating periods of cambium activity in response to seasonal environmental changes, which are mostly driven by climate factors. Cambium dormancy followed by cambial re-activation and declining cambial activity across the growing season induces wood-anatomical changes that ultimately form ring boundaries (Fahn, 1982; Worbes, 1992). Investigating the seasonal cambial activity along with leaf phenology and environmental data is a fundamental approach to verify the annual character of growth rings of any species (Marcati et al., 2006; Pumijumnong and Buajan, 2013). Surprisingly, compared to species from boreal and temperate areas, very few studies on cambial activity have been conducted on tropical species (Priya and Bhat, 1999; Marcati et al., 2006; Venugopal and Liangkuwang, 2007; Marcati et al., 2008; Dié et al., 2012; Pumijumnong and Buajan, 2013; Marcati et al., 2016). The number is even less for mangrove species which reflects a knowledge gap in mangrove studies (Schmitz et al., 2006; Buajan and Pumijumnong, 2012; Chowdhury et al., 2016b). Knowledge of seasonal cambial activity such as identification of the beginning of cambial cell production, cessation, and their duration is therefore essential for a better understanding of intra-annual wood formation in response to environmental changes.

Sonneratia apetala is an ecologically important tree species in mangroves of the Indo-Malayan region (Tomlinson, 1986). It is a light-demanding evergreen tree species belonging to the family of Sonneratiaceae (former Lythraceae) (Rashid and Rahman, 2012). In the Sundarbans, it mostly occurs in monospecific stands and often in association with Avicennia officinalis as a pioneer species in succession, preferably in moderate to high salinity zones (Iftekhar and Saenger, 2008). Considering the importance of conservation of the Sundarbans, a better understanding of environmental factors that may drive the 
growth of $S$. apetala is essential. This study aims at investigating the growth dynamics of $S$. apetala in the Sundarbans by addressing the following research questions: i) do the trees produce periodic distinct growth rings? and ii) to which extent, do climatic (precipitation and temperature) and hydrology-related (salinity) factors affect radial growth?

\section{Materials and methods}

\subsection{Study area and climate}

The study was conducted in the Sundarbans which is situated in the south-western frontiers $\left(21^{\circ} 35^{\prime}-22^{\circ} 30^{\prime} \mathrm{N}, 89^{\circ} 00^{\prime}-89^{\circ} 55^{\prime} \mathrm{E}\right)$ of Bangladesh (Canonizado and Hossain, 1998) (Fig. 1). Out of its total area, about $69 \%$ is land, and the rest comprises rivers, small streams, and canals (Sarker et al., 2016). A significant portion of this forest is washed by the tide twice a day, and the salinity level is related to the combined effects of the tides in the Bay of Bengal and freshwater input from the Ganges trough the Gorai river, the largest river connecting the Sundarbans to the Ganges. Islam and Gnauck (2009) found a significant negative correlation $(\mathrm{r}=-0.86, p<0.05)$ between the Gorai river water discharge and salinity in the Sundarbans (Fig. 2A). To investigate the effect of salinity on the growth of $S$. apetala, we used monsoon (June-September) river discharge data of the Gorai river between 1985 and 2010 as a proxy for salinity due to unavailability of long-term salinity data (Anwar and Takewaka, 2014). Based on salinity, the Sundarbans is divided into three distinct zones: i) low salinity zone (LSZ) (salinity $<14 \mathrm{ppt}$ ), ii) medium salinity zone (MSZ) (salinity 14-25 ppt) and iii) high salinity zone (HSZ) ( $>25 \mathrm{ppt}$ ) (Islam and Gnauck, 2009).

The climate of the study area is strongly seasonal with $87 \%$ of the mean annual rainfall (1500 $\mathrm{mm}$ ) occurring between June to September,
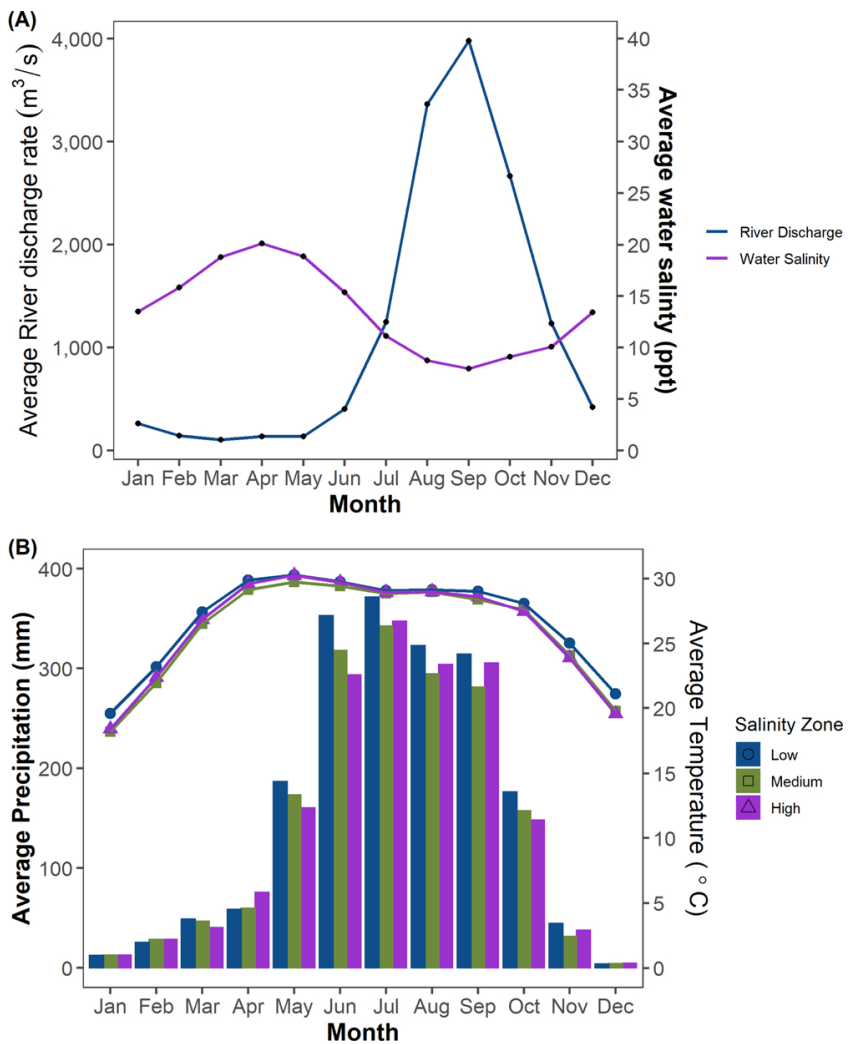

Fig. 2. (A) Monthly average river discharge rate and water salinity in the Sundarbans for the period 1989-1997. (B) Monthly average total precipitation and average temperature in three salinity zones of the Sundarbans for the period 1985-2012. representing the monsoon period (Fig. 2b) (Chowdhury et al., 2016a). The average temperature ranges between $26-29{ }^{\circ} \mathrm{C}$ in pre-monsoon and monsoon season, $26-27{ }^{\circ} \mathrm{C}$ in post-monsoon and $19-21{ }^{\circ} \mathrm{C}$ during the winter season (Fig. 2b). Precipitation and temperature records for the period from 1985 to 2012 were available from the Bangladesh Meteorological Department, Dhaka, and taken from nearby weather stations in Mongla (LSZ), Khulna (MSZ) and Satkhira (HSZ). The average monthly precipitation is significantly higher in LSZ than MSZ and HSZ (ANOVA, $\mathrm{F}_{2,900}=2.92, p<0.05$ ). Similarly, a significantly higher average monthly temperature is prevailing in LSZ than MSZ and HSZ (ANOVA, $\mathrm{F}_{2,924}=65.335, p<0.05$ ).

\subsection{Sample collection and preparation}

In 2014, a total of 17 wood discs were collected from small-sized Sonneratia apetala trees (Diameter at Breast Height (DBH) including bark ranges from 4 to $5 \mathrm{~cm}$ ) for cambial analysis from the medium salinity zone (MSZ). Seven discs were collected in the last week of March (pre-monsoon), another seven in August (monsoon), and the remaining three in November (post-monsoon) in a way to represent the major seasons in the Sundarbans. The fresh wood samples were immediately preserved in a container with ethanol to avoid fungal contamination. In January 2013, 31 stem discs were collected from $S$. apetala trees from the three salinity zones ranging between 5 and $28 \mathrm{~cm}$ in $\mathrm{DBH}$ for tree-ring analysis. Among them, ten discs were collected from LSZ; six were from MSZ, and fifteen were from HSZ (Fig. 1). Wood discs were frozen for one week to prevent insect infestation. All discs were sanded using a sanding machine with gradually increasing grit from 100 to 1200 .

\subsection{Microtome sectioning and light microscopy}

Each sample disc was cut into four small blocks containing xylem, cambium, and phloem. Transversal sections of $10 \mu \mathrm{m}$ thickness were prepared using a GSL1 sledge microtome (Gärtner et al., 2014). The micro-thin sections were stained with a mixture (35:65) of $1 \%$ safranin and alcian blue solution (Jansen et al., 2004), subsequently washed with an ethanol series $(50 \%, 75 \%, 96 \%$, and $100 \%)$ and mounted on microscope slides. We used Roti ${ }^{\circledR}$-Mount (Roth, Germany) for permanent fixation, and excess Roti $^{\circledR}$-Mount was cleared with Roticlear ${ }^{\circledR}$ (Roth, Germany). The micro-thin sections were observed under a light microscope (Leica DM 2500, Germany), equipped with bright-field and polarised light optics with a magnification ranging from 12.5 to 400 times. Polarised light was used to detect birefringence from crystals and developing secondary walls in the unstained section (Rossi et al., 2006; Gričar et al., 2007; Dié et al., 2012). Additionally, we used epi-fluorescence in a microscope using a mercury arc lamp and an Olympus WU filter cube (excitation $330-385 \mathrm{~nm}$, long-pass emission $420 \mathrm{~nm}$ ) to distinguish lignin-rich and cellulose-rich cell walls (Bond et al., 2008; Dié et al., 2012). The images were taken using a Leica camera (DFC 320) attached to the light microscope and the further image was stitched by Microsoft Image Composite Editor (ICE -2.0) and analysed using Fiji image $\mathrm{J}$ software (Schindelin et al., 2012).

\subsection{Assessment of seasonal cambial activity}

We distinguished four distinct zones on the thin sections: i) the cambial zone (CZ) consisting of undifferentiated cambial cells and derivatives and located between the xylem and phloem, ii) the expanding zone (EP) with differentiating, irregular shaped cells with primary cell wall showing and no birefringence (like the cambium and to a lesser extend living parenchyma cells) (Rossi et al., 2006; Dié et al., 2012), iii) the wall thickening zone (WT) with cells in various stages of developing the secondary cell walls and beginning to show birefringence (Gričar et al., 2007; Morel et al., 2015) and iv) the mature xylem (M) with fully developed and lignified cells with thick cell walls showing 

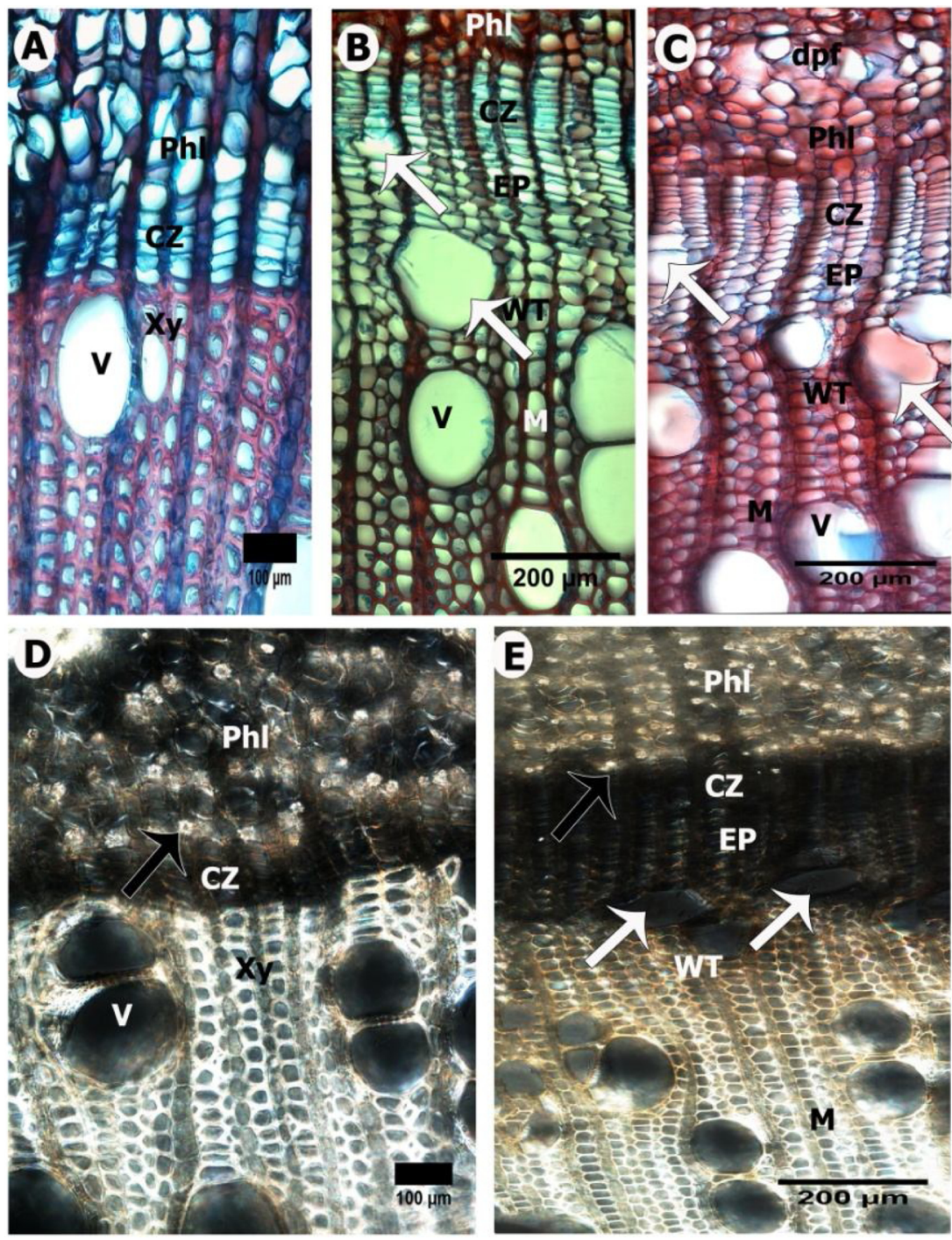

Fig. 3. Seasonal development of cambium and xylogenesis in S. apetala. (A\&D) Dormant cambium in March, (B, C\&E) Active cambium in August and November. Phl $=$ Phloem, $\mathrm{CZ}=$ Cambium zone, $\mathrm{Xy}=$ Xylem, $\mathrm{EP}=$ Expanding zone, $\mathrm{WT}=$ Wall Thickening zone, $\mathrm{M}=$ Mature zone, $\mathrm{V}=$ Vessels, $\mathrm{dpf}=$ Developing phloem fibres. White arrow $=$ Developing vessels, Black arrow = crystals. Methods: TS (A-E); BF (A-C) and PL (D-E), Where, TS: transverse section; BF: bright-field light microscopy; PL: polarized light.

birefringence. From each digital image, the number of radial cell layers, and width of the cambial zone in the radial and tangential direction were measured along with three continuous cellular files in each zone (Deslauriers et al., 2003; Rossi et al., 2006). Twelve counted values from each image were used for further calculations.

\subsection{Compilation of growth ring chronologies}

On the sanded discs, growth-ring boundaries were marked with a pencil under a stereomicroscope in three radii from pith to bark to check for ring anomalies (Fig. A1A). In the case of anomalies (false rings and particularly locally absent rings), every tree ring was followed along the tree circumference. Ring widths were measured with a resolution of $0.01 \mathrm{~mm}$ by using a stereomicroscope and a Lintab measuring device with TSAP-Win software (Rinn, 2003). To ensure assigning each tree ring to the exact calendar year, crossdating was done between individual tree ring series (Douglass, 1941). We cross-dated tree-ring series by visual comparison among the trees and using the Student's $t$ (Baillie and Pilcher, 1973) and Gleichläufigkeit values (GLK) by TSAP-WIN software (Eckstein and Bauch, 1969). The cross-dating threshold was set in this study at a $t$-value of $2.0(p<0.05)$ and a GLK of 60 \% (Trouet et al., 2010; De Ridder et al., 2013). Crossdating of tree ring series per salinity zone was also done by averaging ring series into an individual tree series. Successful crossdating of trees thus indicates a common external factor influencing the growth of the trees (Cook and Kairiukstis, 1990; Worbes, 1995).

Each of the raw series were detrended by fitting a 10-year cubic smoothing spline with the degree of smoothing at 50\% frequency response to eliminate or minimise the long-term and low-frequency variation due to age. Residual chronologies were calculated for the three sites, resembling salinity regimes, from the detrended ring width series by calculating a bi-weight robust mean (Cook and Kairiukstis, 1990) using dplR package (Bunn, 2008) in R statistical software (R Core Team, 2019). The statistical parameters were calculated for each residual chronology. The first-order autocorrelation (AC1) was done to detect eventual persistence of growth variation after standardisation, and the mean sensitivity (MS) is an evaluation of high-frequency year-to-year variations in a tree ring width (Fritts, 1976). A mean sensitivity is considered as high when it is greater than 0.30, according to Ferguson's classification (Savva et al., 2006). As an indicator of the reliability of each chronology, the mean tree ring series correlation (RBAR) and the Expressed Population Signal (EPS) were calculated (Cook and 
Kairiukstis, 1990). The EPS measures to what extent the sample chronology could be representative of the theoretical population (Wigley et al., 1984) whereas, RBAR is the mean inter-series correlation coefficient. A chronology with an EPS $>0.85$ is often considered to be reliable (Cook and Kairiukstis, 1990). Signal to noise ratio (SNR) is an expression of the strength of the observed common signal among trees (Wigley et al., 1984).

\subsection{Statistical analysis}

All wood anatomical parameters were analysed by analysis of variance (ANOVA) and Welch's test after having examined the normality with the Shapiro-Wilk test and uniformity of variances with Leven's test using SPSS v.21.0. In the case of unequal variances, we used Welch's ANOVA (Quinn and Keough, 2002; Ruxton, 2006). The radial growth rate in three salinity zones was analysed by ANOVA with the General Linear Model (GLM), where diameter class was considered as a fixed factor. To investigate the effects of seasonal climatic and environmental factors on tree growth, the data were detrended by fitting a 10-year cubic smoothing spline method before analysis to focus on the drivers of annual growth variability. Therefore, all climatic parameters were expressed as deviations from the long-term trend. Furthermore, Pearson's correlation analysis was done for the chronologies from the three salinity zones (HSZ, MSZ and LSZ) with standardised monsoon season (June to September) precipitation, temperature, and river discharge, respectively.

\section{Results}

\subsection{Seasonal variation of cambial activity}

Apart from the phloem, four different zones, i.e. cambium zone (CZ), expanding zone (EP), wall thickening zone (WT) and mature xylem (M) were clearly detected on the thin sections under bright-field, polarised light and fluorescence microscopy in the samples taken in the monsoon and post-monsoon period, respectively in August and November (Figs. $3 \& 4$ ). The lack of the EP and WT zone in samples taken in March (Figs. 3A, D \& 4 A), indicated the absence of cambial activity in the pre-monsoon period. Therefore, the demarcation boundary between $\mathrm{M}$ and $\mathrm{CZ}$ was gradual in the samples that were collected in August and November in contrast to the samples of March, where the transition from the mature tissue formed in the previous year to the cambial zone was abrupt. Recent cell divisions, as indicated by the presence of a thin cell wall in cells in direct vicinity to the CZ were visible in samples collected in August and November and lacking in the samples of March. The number of cells in the CZ ranges from 7 to 15, whereas the samples of March showed only 4 to 7 cambial cells (Table 1). The average number of cambial cells and the width of the $\mathrm{CZ}$ were significantly higher in the samples of August and November than those of March (for cambial cell number, Welch's ANOVA, $\mathrm{F}_{2,65}=$ 394.5, $p<0.001$, for cambial width, Welch's ANOVA, $\mathrm{F}_{2,65}=111.2$, $p<0.001)$. Interestingly, the average radial diameter of cambial cells and the tangential width of cambial ray initial cells were significantly larger in the samples of March than those of August and November (for cambial cell's radial diameter, Welch's ANOVA, $\mathrm{F}_{2,65}=394.5$, $p<0.001$, for cambial ray cell's tangential width, Welch's ANOVA, $\mathrm{F}_{2,65}=345.3, p<0.001$ ). However, the average tangential diameter of cambial cells was significantly higher in the samples collected in August and November (Welch's ANOVA, $\mathrm{F}_{2,65}=90.4, p<0.001$ ).

\subsection{Growth ring characteristics}

S. apetala has diffuse-porous wood with distinct growth ring boundaries that are marked by radially flattened fibres (Fig. A1). However, the distinctness of these growth ring boundaries varied between trees from the three salinity zones, with more conspicuous ring boundaries occurring in trees from the higher salinity zone. False and locally absent rings complicated ring detection in trees from all salinity zones. The average radial growth rate ranges from 2.00 to $5.70 \mathrm{~mm}$ per year in all salinity zones and ANOVA test revealed that both salinity zones and diameter class had a significant effect on the growth rate of this species (for salinity zones, $\mathrm{F}_{2,68}=22.3, p<0.05$ and diameter class, $F_{2,68}=17.4, p<0.05$ ). The higher growth rate was observed in higher diameter trees irrespective of the salinity zone. The corresponding LSD pair-wise comparison test showed that the average growth rate between LSZ and MSZ was not significant $(p>0.05)$; however, a significantly lower growth rate was in the HSZ $(p<0.05)$.

Despite having missing, locally absent rings and variable distinctness of ring boundaries, it was possible to crossdate the ring-width series visually and statistically and calculate ring-width chronologies for the trees in the three salinity zones covering a period of respectively 25 years (LSZ) and 28 years (MSZ and HSZ; Fig. 5). Pearson correlation test among the three chronologies reveals that all three chronologies correlated positively with each other (LSZ and MSZ, $\mathrm{r}=0.66, p<0.05$, LSZ and HSZ, $\mathrm{r}=0.64, p<0.05$, and MSZ and HSZ, $\mathrm{r}=0.7, p<0.05$ ). The positive correlations among the chronologies indicate that there is a common external factor influencing the growth of this species. The $S$. apetala tree ring chronologies are representing the population signal as indicated by high intercorrelation as well as EPS values (Table 2). The lower first-order autocorrelation (AC1) in all three zones indicates the lower influence of external factors from the previous year to the current year's ring width. The similar average mean sensitivity (MS) ranged from 0.45 to 0.47 indicates that all the chronologies showed high-frequency inter-annual variations. Moreover, similar high average interseries correlation (Rbar) and expressed population signal (EPS) indicating the existence of high common signals and poses the suitability of the chronologies for dendrochronological studies.

\subsection{Relation of growth with climate and river discharge}

The chronologies from all three salinity zones showed a significant positive correlation with river discharge rate during the monsoon season (June-September) (Table 3). Clear differences in response to monsoon precipitation and temperature can be seen between trees growing in the three salinity zones. $S$. apetala trees growing in the zone with lower salinity (LSZ) show a significant positive response to monsoon precipitation and a significant negative response to monsoon temperature. Trees growing under higher salinity regimes in the MSZ and HSZ still react positively to precipitation and negatively to temperature during the monsoon period, but the relation is much weaker.

\section{Discussion}

\subsection{Sonneratia apetala forms annual growth rings}

In this study, we found that the cambium of $S$. apetala is still dormant in March (starting month of pre-monsoon) but active during August and November, i.e. the period of monsoon and post-monsoon when precipitation, temperature and river discharge are quite high (Fig. 2). The distinction into zones defining the cell developmental stages worked well to assess seasonality in wood formation (Figs. 3 \& 4). The lower number of cells with thicker radial cell walls, both in the cambium zone (CZ) was a clear indicator of dormancy (Table 1). The thicker radial walls of the cambial cells might be related to apoplastic translocation during the dormant period through the cambial zone from xylem to phloem parenchyma cells which usually stores food during the active period (Catesson, 1994). This together with the lack of enlarging cells and cells in cell wall lignification stage are widely used for characterisation of the dormant cambium in the tropics (Larson, 1994; Marcati et al., 2008; Dié et al., 2012; Pumijumnong and Buajan, 2013; Chowdhury et al., 2016b).

Conversely, active cambium was found in the samples of August 


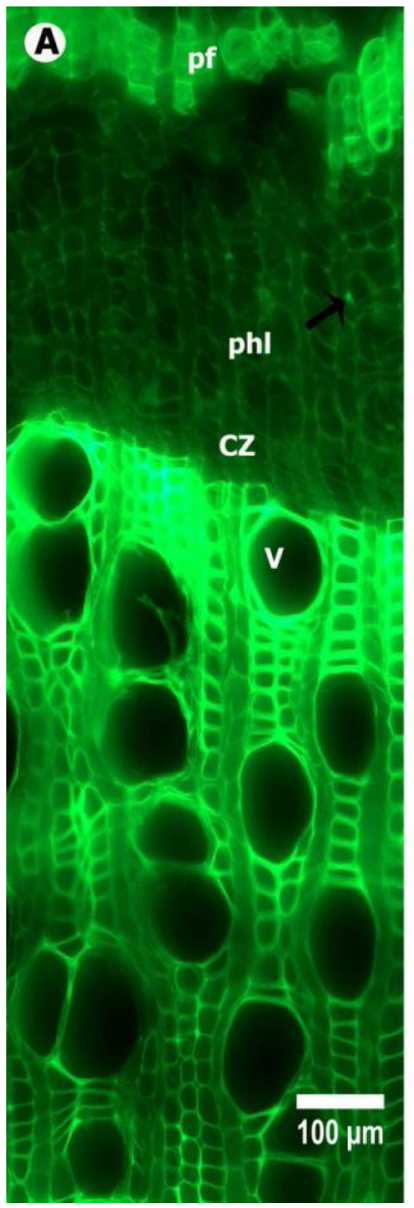

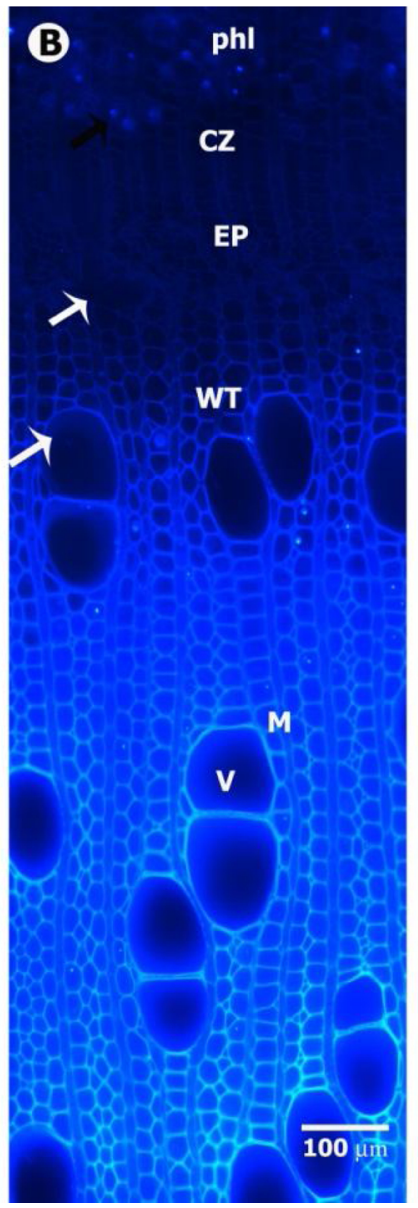

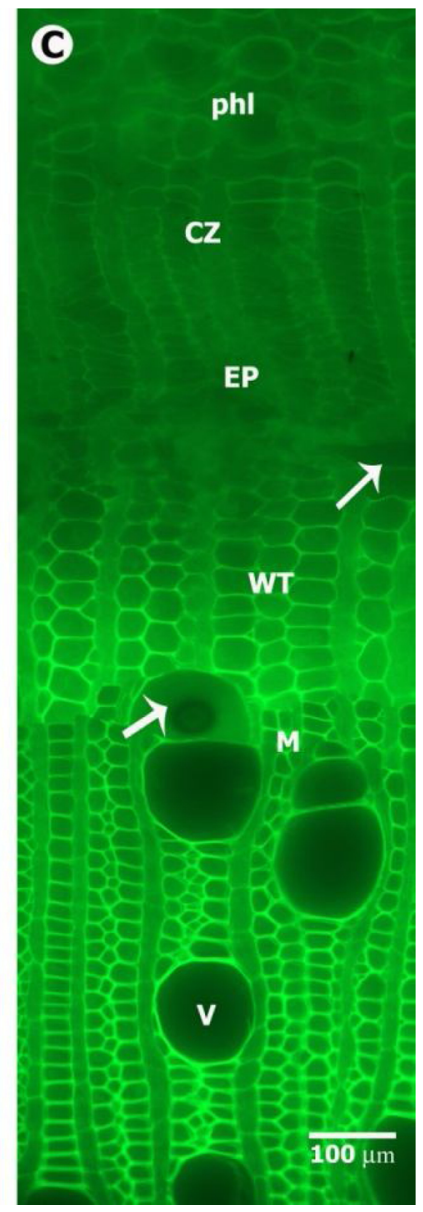

Fig. 4. Seasonal development of xylogenesis in $S$. apetala. (A) No cell differentiation in March, (B) \& (C) Differentiation of xylem elements in August and November. Phl $=$ Phloem, $\mathrm{CZ}=$ Cambium zone, EP = Expanding zone, $\mathrm{WT}=$ Wall Thickening zone, $\mathrm{M}=$ Mature zone, $\mathrm{V}=$ Vessels, pf $=$ Phloem fibres, White arrow = Developing vessels, Black arrow = crystals. Methods: TS (A-C); FL (A-C), Where, TS, transverse section; FL, epi-fluorescence light. (monsoon) and November (post-monsoon). The samples of both seasons show a gradual transition from the CZ to mature xylem (M) due to the presence of expanding zone (EP) and wall thickening zone (WT) (Figs. 3 \& 4). The initial cells divided periclinally, producing xylem and phloem mother cells that divided through repeated tangential (anticlinal) divisions occurring on both sides of the radial file leading to an increased number of the cambial cells and wider cambial zone (Larson, 1994). The large size of the cambium, as well as other xylem differentiating zones in August, are related to the lower salinity during monsoon and the presence of mature leaves for active photosynthesis. From November to March (Fig. 2), the lower monthly precipitation ( $<40 \mathrm{~mm}$ ) and a decrease of up-stream river flows (57-69\%) leads to an increase in salinity (80 \%) in the Sundarbans (Mirza, 1998; Wahid et al., 2007; Islam and Gnauck, 2011). Despite the on average lower precipitation in the post-monsoon period, the active cambium in November suggests that due to the effects of previous months and moderate river discharge, the salinity is still within the tolerance level for this species.
However, the lack of anticlinal division as observed in the cambium in November likely indicates the transition from an active to a dormant cambium (Iqbal, 1990; Venugopal and Krishnamurthy, 1994). It is also noted that an annual dry season lasting for 2 to 3 months with minimum precipitation ( $<60 \mathrm{~mm}$ ) triggering the cambial dormancy in the tropical species for the ring formation (Worbes, 1995; Trouet et al., 2010). The samples of March also showed that trees already produced three to five rows of flattened fibres as the dormant cambium (Fig. A2). The increase of precipitation might induce cambial reactivation during late pre-monsoon or onset of monsoon and trees to produce new xylem with the different anatomy, as evident in the samples of August and November. Although our cambium sampling scheme did not allow us a precise reconstruction of seasonal cambial activity throughout the year, it enabled to verify annual growth-ring formation and indicated the relevance of salinity for the growth of $S$. apetala. To precisely derive seasonal growth dynamics multi-annual and frequent, e.g. weekly or biweekly micro sampling or cambium marking campaigns are

Table 1

Seasonal variation of cambial morphology in the medium salinity zone (MSZ).

\begin{tabular}{|c|c|c|c|c|c|c|}
\hline Months & $\begin{array}{l}\text { Range of Cambial } \\
\text { cells }\end{array}$ & $\begin{array}{c}\text { Average } \\
\text { no. of cambial } \\
\text { cell }\end{array}$ & $\begin{array}{c}\text { Average } \\
\text { cambial } \\
\text { zone width } \\
(\mu \mathrm{m})\end{array}$ & $\begin{array}{l}\text { Average cambial cells radial } \\
\text { diameter }(\mu \mathrm{m})\end{array}$ & $\begin{array}{l}\text { Average cambial cells tangential } \\
\text { diameter }(\mu \mathrm{m})\end{array}$ & $\begin{array}{l}\text { Average ray cambium cells } \\
\text { tangential width }(\mu \mathrm{m})\end{array}$ \\
\hline March & $4-7$ & $5.3 \pm 0.1^{c}$ & $79.9 \pm 1.6^{c}$ & $13.1 \pm 0.2^{\mathrm{a}}$ & $38.9 \pm 0.4^{c}$ & $20.1 \pm 0.3^{\mathrm{a}}$ \\
\hline August & $7-15$ & $10.3 \pm 0.2^{b}$ & $98.8 \pm 3.5^{b}$ & $8.9 \pm 0.1^{c}$ & $35.6 \pm 0.3^{b}$ & $12.2 \pm 0.1^{\mathrm{c}}$ \\
\hline November & $10-15$ & $12.9 \pm 0.2^{\mathrm{a}}$ & $146.9 \pm 4.6^{\mathrm{a}}$ & $9.9 \pm 0.2^{b}$ & $40.2 \pm 0.2^{\mathrm{a}}$ & $13.6 \pm 0.3^{b}$ \\
\hline Welch's test, F & & 394.5 & 111.2 & 134.8 & 90.4 & 345.3 \\
\hline$p$ & & $<0.001$ & $<0.001$ & $<0.001$ & $<0.001$ & $<0.001$ \\
\hline
\end{tabular}

Note: Average values followed by different letters indicate significantly different means between different months. (Mean \pm s.e.; Welch's ANOVA test followed by post hoc Games-Howell pair-wise comparison test at $p<0.05$ ). 


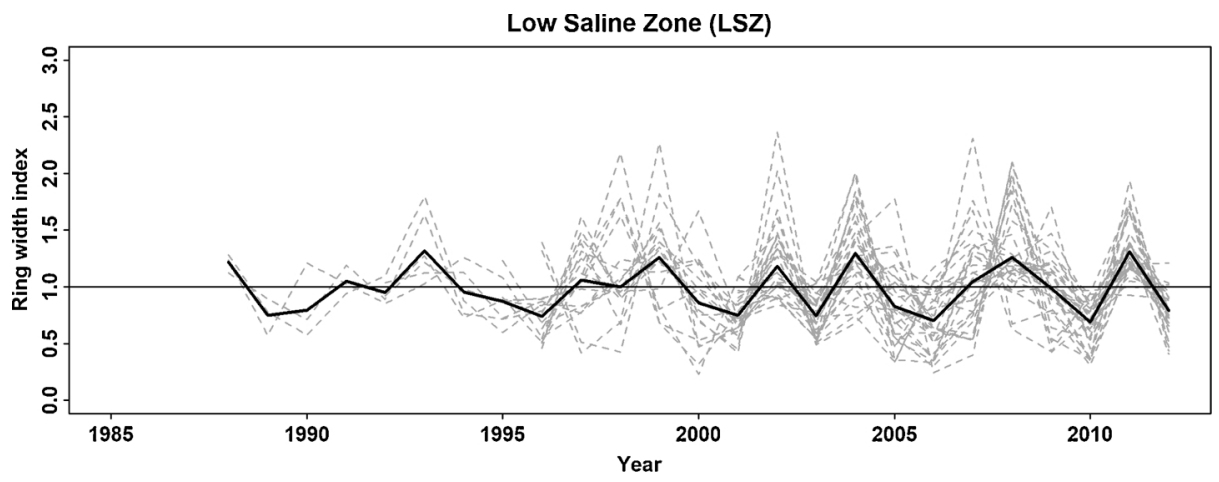

Medium Saline Zone (MSZ)

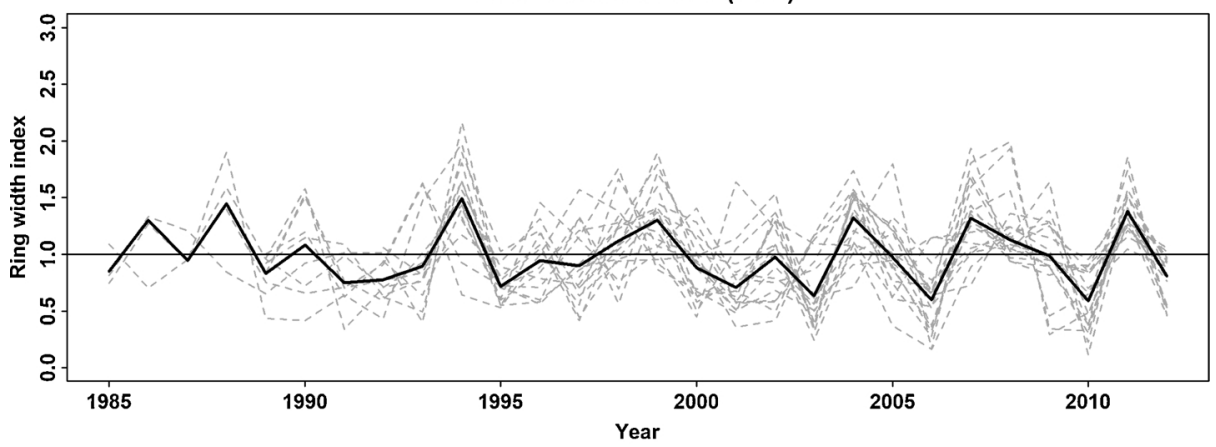

High Saline Zone (HSZ)

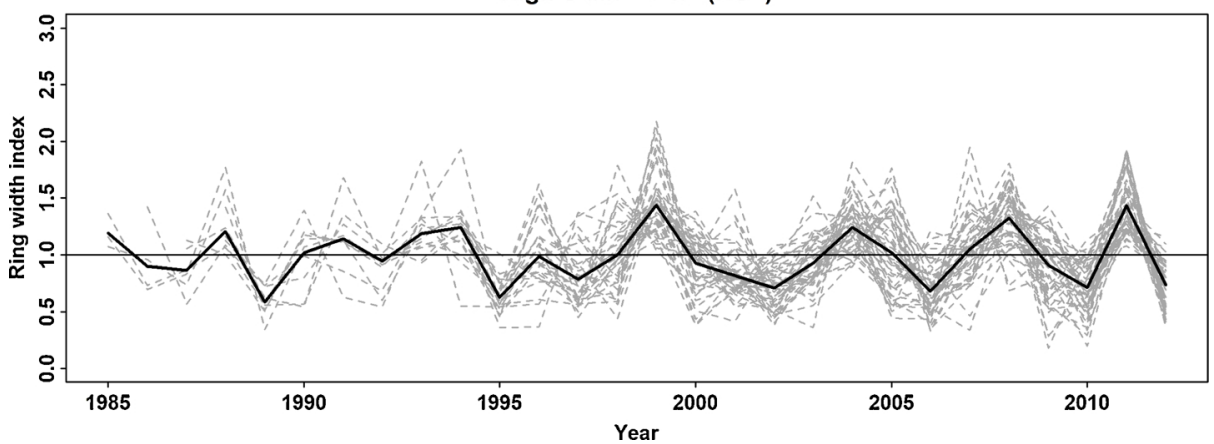

Fig. 5. Standard ring width chronology of three salinity zones (Top $=$ LSZ, Middle $=$ MSZ and bottom $=$ HSZ). The horizontal dashed grey lines are the individual series and bold black line is their 10 year running average.

Table 2

Mean statistical attributes of crossdated ring-width series of $S$. apetala in three salinity zones.

\begin{tabular}{|c|c|c|c|}
\hline Variables & Low salinity zone (LSZ) & Medium salinity zone (MSZ) & High salinity zone (HSZ) \\
\hline Number of trees & 10 & 6 & 15 \\
\hline Number of transects & 30 & 18 & 45 \\
\hline Average stem diameter $(\mathrm{cm})$ & $13.11(8.9-17.4)$ & $21.4(14.8-28.1)$ & $9.85(5.6-21.5)$ \\
\hline Average age (years) & $16(11-25)$ & $22(16-28)$ & $19(12-28)$ \\
\hline Time span (years) & $1988-2012$ & $1985-2012$ & $1985-2012$ \\
\hline Average ring width $(\mathrm{mm}) \pm \mathrm{SD}$ & $3.11( \pm 1.23)$ & $4.39( \pm 1.98)$ & $2.39( \pm 0.89)$ \\
\hline 1 st order autocorrelation (AC1) & 0.32 & 0.18 & 0.18 \\
\hline Standard Deviation & 0.38 & 0.42 & 0.37 \\
\hline Mean sensitivity (MS) & 0.47 & 0.47 & 0.45 \\
\hline t-value $\mathrm{BP}( \pm \mathrm{SD})$ & $5( \pm 2)$ & $6( \pm 2)$ & $8( \pm 3)$ \\
\hline GLK $( \pm \mathrm{SD}, \%)$ & $83( \pm 3)$ & $78( \pm 3)$ & $86( \pm 3)$ \\
\hline Expressed population signal (EPS) & 0.96 & 0.95 & 0.98 \\
\hline The signal to noise ratio (SNR) & 24.31 & 17.08 & 38.27 \\
\hline Mean interseries correlation (Rbar) & 0.55 & 0.55 & 0.56 \\
\hline
\end{tabular}

Note: $\mathrm{LSZ}=$ Low salinity zone, MSZ = Medium salinity zone and HSZ = High salinity zone. t-value BP = t-value Baillie Pilcher, GLK = Gleichläufigkeitskoeffizient. Value in the parentheses is range. 
Table 3

Correlation coefficient of standard chronologies from all salinity zones with climatic and environmental factors.

\begin{tabular}{|c|c|c|c|c|}
\hline Zone & & River discharge rate & Precipitation & Temperature \\
\hline \multirow[t]{3}{*}{ Low salinity zone (LSZ) } & Standard chronology & $0.47^{*}$ & $0.57^{* *}$ & $-0.49^{*}$ \\
\hline & River discharge & & 0.26 & -0.18 \\
\hline & Precipitation & & & -0.13 \\
\hline \multirow[t]{3}{*}{ Medium salinity zone (MSZ) } & Standard chronology & $0.44^{*}$ & 0.20 & -0.26 \\
\hline & River discharge & & 0.14 & -0.25 \\
\hline & Precipitation & & & -0.04 \\
\hline \multirow{3}{*}{ High salinity zone (HSZ) } & Standard chronology & $0.62^{* *}$ & 0.27 & -0.38 \\
\hline & River discharge & & 0.22 & -0.20 \\
\hline & Precipitation & & & -0.20 \\
\hline
\end{tabular}

recommended (Verheyden et al., 2004; Schmitz et al., 2007; Chowdhury et al., 2016b). Seen the considerable working load for collection, preparation and analyses of micro samples or cambial marks, the use of dendrometers is also recommended (Robert et al., 2014).

\subsection{Sonneratia apetala growth is mainly driven by salinity}

Although growth rings of $S$. apetala have found to be annual, the presence of false rings and locally absent rings categorises this species as indistinct to a distinct growth ring (Wheeler, 2011). These anomalies might be associated with phases of low growth rates or asymmetrical stem growth in mangroves (Chowdhury et al., 2016b), which is also common in other tropical species (Trouet et al., 2010; De Ridder et al., 2013; Mbow et al., 2013). Stem asymmetry can also be related to growth stress during stem development due to inundation, sedimentation, erosion, seasonal storms and anthropogenic disturbances (Ellison et al., 2000; Robert et al., 2011). The possibility to crossdate growth ring within and among the samples of $S$. apetala provides strong evidence that the growth rings are indeed annual driven by seasonality in climate and environmental factors as suggested in previous studies by Chowdhury et al. (2008) and Maxwell et al. (2018). When comparing growth ring series of $S$. apetala from the Sundarbans studied by Maxwell et al. (2018) with those of our trees from the low (LSZ) (Fig. A3) and high (HSZ) salinity zone, no match was found (for LSZ, $r=0.01$, $p>0.05$, and for HSZ, $\mathrm{r}=0.00, p>0.05$ ); our MSZ chronology even showed a negative correlation $(\mathrm{r}=-0.15, p>0.05)$. Although the sample collection site of Maxwell et al. (2018) originated from LSZ, they collected samples from the seaward side of the Sundarbans where there might be some external influence of the sea. On the other hand, our samples originated from the landward side- free from the direct influence of the sea. These differences, which can occur through short distances in the same study area indicate the importance of the specific environmental settings especially related to salinity for the growth of $S$ apetala and most likely also other mangrove species. This is supported by the chronology statistics yielded for the three salinity zones (Table 2), which indicates that the three chronologies show variable signals related to micro-climate variation of the three salinity zones or exogenic influences such as ocean Ell Nino oscillation or sea-level rise (Wigley et al., 1984; Maxwell et al., 2018).

In the low salinity zone (LSZ), the average radial growth of $S$. apetala is considerably higher than that those of medium (MSZ) and higher salinity (HSZ) zone (Table 2). The average radial growth rate $(3.02 \pm 1.20 \mathrm{~mm})$ is within the range of the earlier study of Chowdhury et al. (2008), where the ring width ranges from 0.40 to $7.00 \mathrm{~mm}$ with an average of $2.00 \pm 1.00 \mathrm{~mm}$. The lower growth rate in the higher salinity zone indicates a negative influence on tree physiology (Siddiqi et al., 1989). Yan and Guizhu (2007) found a sharp decrease of the photosynthetic rate of $S$. apetala above 15 ppt (parts per trillion $\left(10^{12}\right)$ ) salinity in a controlled experiment which likely has a negative effect on radial growth. The higher salinity stress due to lower freshwater input might be reflected as more unfavourable growth conditions for trees
(Menezes et al., 2003; Robert et al., 2011). The range of average growth rate of $S$. apetala corresponds well with Rhizophora mucronata (0.50-4.81 $\mathrm{mm}$ year $^{-1}$ ) from Gazi Bay, Kenya (Verheyden et al., 2004), but higher growth rate exhibited than Avicennia marina $(1.00 \mathrm{~mm}$ year $^{-1}$ ) from Kenya (Schmitz et al., 2008), Xylocarpus granatum (0.62-2.51 mm year $\left.{ }^{-1}\right)$, Bruguiera gymnorrhiza $\left(0-2.51 \mathrm{~mm}_{\text {year }}{ }^{-1}\right)$, Rhizophora mucronata $\left(0.94 \mathrm{~mm} \mathrm{year}^{-1}\right)$ and Sonneratia alba (0.31-1.25 $\mathrm{mm}$ year $^{-1}$ ) from Micronesia (Devoe and Cole, 1998), Heritiera fomes ( 0.86 to $1.40 \mathrm{~mm} \mathrm{year}^{-1}$ ) from the Sundarbans (Chowdhury et al., 2008, 2016a, 2016b) and lower than Avicennia marina $(4.84 \mathrm{~mm}$ year $^{-1}$ ) from Western Australia (Santini et al., 2013). Overall, the range of radial growth rate in different species from different continents shows that mangroves usually have a low growth rate in comparison to terrestrial tree species. However, for this type of comparison, confounding factors, such as environment, ontogeny, and inter-generic differences, are important to consider (Robert et al., 2011).

Irrespective of salinity zones, we could prove that river discharge during the monsoon season, i.e. from June to September, was positively related to the growth a $S$. apetala (Table 3). Several studies confirmed that the upstream river discharge rate is negatively correlated with salinity in the Sundarbans and a higher discharge positively affects the growth dynamics of mangroves in the Sundarbans (Wahid et al., 2007; Islam and Gnauck, 2009; Rahaman et al., 2014; Dasgupta et al., 2015, 2017). Our $S$. apetala trees in the lower salinity zone (LSZ) show, in addition to the positive relation to river discharge, a significant positive correlation with monsoon precipitation and a negative correlation with monsoon temperature. Similarly, Maxwell et al. (2018) also found a positive correlation between the growth and monsoon precipitation of $S$. apetala collected from low salinity zones. However, they concluded that the trees are not sensitive to salinity as they found a negative correlation with the dry season precipitation. An intolerance to salinity might hold for trees in low salinity areas, i.e. under conditions where the salinity is within the tolerance level of the species. This phenomenon does not hold for the trees in our sites as we found a strong relation with river discharge and climate factors prevailing in the monsoon period in all salinity zones. Mangrove physiology although adapted to salinity is generally favoured by lower salinity, but also lower temperature during the growing period as the high temperature increases water loss due to transpiration (Tomlinson, 1986; Reef and Lovelock, 2015). The fact that the relation with climate factors is strongest in the low salinity zone was surprising but highlighted the complex interaction between freshwater input from the river and the sky as well as evaporation and evapotranspiration loss triggered by high temperature.

Altogether, river discharge rate in combination with high precipitation and low temperature conditions during the monsoon season had a significant effect of reducing the salinity and in turn favour the growth of Sonneratia apetala. Besides, the growth variation of this species could also be linked with ocean oscillations as pointed out by Maxwell et al. (2018). The sensitivity to higher salinity, especially in the MSZ and HSZ, could be helpful to understand the ecology of this species in the Sundarbans, particularly with the rising sea level and the consequent rising salinity. 


\section{Conclusion}

The analysis of seasonal cambium activity and the success of growth ring crossdating proved the existence of distinct annual growth rings in $S$. apetala driven by a distinct seasonality of salinity. The presence of annual growth rings provides a solid basis for age and growth rate determination which has necessary implications for understating the ecology of the species. The growth of $S$. apetala is mainly driven by freshwater input through river discharge and precipitation during the monsoon season. With the predicted sea-level rise and its consequences on rising salinity, our results suggest that $S$. apetala will likely experience adverse effects of climate change and global warming in the future with the declined growth rate. Besides offering the possibility to evaluate the impact of future changes in these factors on mangrove growth in the Sundarbans, the strong relationship between $S$. apetala growth and environmental factors provides the chance of reconstructing past climate and river discharge or salinity in this region provided that longer chronologies can be constructed.

\section{Funding}

The study was funded by Netherlands Fellowship Programme (NFP) under NUFFIC (The Dutch Organisation for Internationalisation in Education) (Grant number: NFP-MA.13/ 7623, 2013).

\section{Conflict of interest}

The authors agreed that they have no conflict of interest.

\section{Acknowledgements}

We are thankful to Ellen Boerstra-Wilderink and Dr. Norbert de Ruijter for their help during laboratory work on wood anatomy and microscopic imaging. We also express our gratitude to Md. Toufiqul Islam (Bangladesh Forest Department), Mohammad Raqibul Hasan Siddique, Sanjay Saha and Siddikur Rahman Rana (Khulna University, Bangladesh) for their support during the fieldwork. We extend our gratitude to the three anonymous reviewers for their valuable comments and suggestions which substantially improved our manuscript.

\section{Appendix A. Supplementary data}

Supplementary material related to this article can be found, in the online version, at doi:https://doi.org/10.1016/j.dendro.2020.125711.

\section{References}

Alongi, D.M., 2015. The impact of climate change on mangrove forests. Curr. Climate Change Rep 1, 30-39. https://doi.org/10.1007/s40641-015-0002-x.

Amobi, C., 1974. Periodicity of wood formation in twigs of some tropical trees in Nigeria. Ann. Bot. 38, 931-936. https://doi.org/10.1093/oxfordjournals.aob.a084887.

Anwar, M.S., Takewaka, S., 2014. Analyses on phenological and morphological variations of mangrove forests along the southwest coast of Bangladesh. J. Coast. Conserv. 18, 339-357. https://doi.org/10.1007/s11852-014-0321-4.

Baillie, M.G., Pilcher, J.R., 1973. A simple crossdating program for tree-ring research. Tree-Ring Bull. 33, 7-14.

Bond, J., Donaldson, L., Hill, S., Hitchcock, K., 2008. Safranine fluorescent staining of wood cell walls. Biotech. Histochem. 83, 161-171. https://doi.org/10.1080/ 10520290802373354.

Brienen, R.J.W., Lebrija-trejos, E., Zuidema, P.A., Martínez-ramos, M., 2010. Climategrowth analysis for a Mexican dry forest tree shows strong impact of sea surface temperatures and predicts future growth declines. Glob. Change Biol. Bioenergy 16, 2001-2012. https://doi.org/10.1111/j.1365-2486.2009.02059.x.

Buajan, S., Pumijumnong, N., 2012. Seasonal cambial activity of some mangrove trees in Inner Gulf of Thailand in dependence on climate. Songklanakarin J. Sci. Technol. 34, 337-344.

Bunn, A.G., 2008. A dendrochronology program library in R (dplR). Dendrochronologia 26, 115-124. https://doi.org/10.1016/j.dendro.2008.01.002.

Canonizado, J., Hossain, M., 1998. Integrated Forest Management Plan for the Sundarbans Reserved Forest. Mandala Agricultural Development Corporation and Bangladesh Forest Department, Dhaka, Bangladesh.
Catesson, A.-M., 1994. Cambial ultrastructure and biochemistry: changes in relation to vascular tissue differentiation and the seasonal cycle. Int. J. Plant Sci. 155, 251-261. https://doi.org/10.1086/297165.

Chaudhuri, A.B., Choudhury, A., 1994. Mangroves of the Sundarbans. Volume 1: India. International Union for Conservation of Nature and Natural Resources (IUCN), Gland 247 pp.

Chowdhury, M.Q., Schmitz, N., Verheyden, A., Sass-Klaassen, U., Koedam, N., Beeckman, H., 2008. Nature and periodicity of growth rings in two Bangladeshi mangrove species. IAWA J. 29, 265. https://doi.org/10.1163/22941932-90000185.

Chowdhury, M.Q., De Ridder, M., Beeckman, H., 2016a. Climatic signals in tree rings of Heritiera fomes Buch.-Ham. in the Sundarbans, Bangladesh. PLoS One 11, e0149788. https://doi.org/10.1371/journal.pone.0149788.

Chowdhury, M.Q., Kitin, P., De Ridder, M., Delvaux, C., Beeckman, H., 2016b. Cambial dormancy induced growth rings in Heritiera fomes Buch.- Ham.: a proxy for exploring the dynamics of Sundarbans, Bangladesh. Trees 30, 227-239. https://doi.org/10. 1007/s00468-015-1292-2.

Church, J.A., Clark, P.U., Cazenave, A., Gregory, J.M., Jevrejeva, S., Levermann, A. Merrifield, M.A., Milne, G.A., Nerem, R.S., Nunn, P.D., Payne, A.J., Pfeffer, W.T., Stammer, D., Unnikrishnan, A.S., 2013. Sea level change. In: Stocker, T.F., Qin, D., Plattner, G.-K., Tignor, M., Allen, S.K., Boschung, J., Nauels, A., Xia, Y., Bex, V., Midgley, P.M. (Eds.), Climate Change 2013: The Physical Science Basis. Contribution of Working Group I to the Fifth Assessment Report of the Intergovernmental Panel on Climate Change. Cambridge University Press, New York, pp. 1137-1216.

Collins, M., Knutti, R., Arblaster, J., Dufresne, J.-L., Fichefet, T., Friedlingstein, P., Gao, X., Gutowski, W.J., Johns, T., Krinner, G., Shongwe, M., Tebaldi, C., Weaver, A.J., Wehner, M., 2013. Long-term climate change: projections, commitments and irreversibility. In: Stocker, T.F., Qin, D., Plattner, G.-K., Tignor, M., Allen, S.K., Boschung, J., Nauels, A., Xia, Y., Bex, V., Midgley, P.M. (Eds.), Climate Change 2013: The Physical Science Basis. Contribution of Working Group I to the Fifth Assessment Report of the Intergovernmental Panel on Climate Change. Cambridge University Press, New York, pp. 1029-1136.

Cook, E.R., Kairiukstis, L.A., 1990. Methods of Dendrochronology: Applications in the Environmental Sciences. Springer $288 \mathrm{pp}$.

Core Team, R., 2019. R: a Language and Environment for Statistical Computing. R Foundation for Statistical Computing, Vienna, Austria. https://www.R-project.org/.

Dahdouh-Guebas, F., Koedam, N., 2008. Long-term retrospection on mangrove development using transdisciplinary approaches: a review. Aquat. Bot. 89, 80-92. https:// doi.org/10.1016/j.aquabot.2008.03.012.

Dahdouh-Guebas, F., Mathenge, C., Kairo, J., Koedam, N., 2000. Utilization of mangrove wood products around Mida Creek (Kenya) amongst subsistence and commercial users. Econ. Bot. 54, 513-527. https://doi.org/10.1007/BF02866549.

Dasgupta, S., Hossain, M.M., Huq, M., Wheeler, D., 2015. Climate change and soil salinity: the case of coastal Bangladesh. Ambio 44, 815-826. https://doi.org/10.1007/ s1328.

Dasgupta, S., Sobhan, I., Wheeler, D., 2017. The impact of climate change and aquatic salinization on mangrove species in the Bangladesh Sundarbans. Ambio 46, 680-694. https://doi.org/10.1007/s13280-017-0911-0.

De Ridder, M., Trouet, V., Van den Bulcke, J., Hubau, W., Van Acker, J., Beeckman, H., 2013. A tree-ring based comparison of Terminalia superba climate-growth relationships in West and Central Africa. Trees 27, 1225-1238. https://doi.org/10.1007/ s00468-013-0871-3.

Deslauriers, A., Morin, H., Begin, Y., 2003. Cellular phenology of annual ring formation of Abies balsamea in the Quebec boreal forest (Canada). Can. J. For. Res. 33, 190-200. https://doi.org/10.1139/x02-178.

Devoe, N.N., Cole, T.G., 1998. Growth and yield in mangrove forests of the Federated States of Micronesia. For. Ecol. Manage. 103, 33-48. https://doi.org/10.1016/S03781127(97)00176-X.

Dié, A., Kitin, P., Kouamé, F.N.G., Van den Bulcke, J., Van Acker, J., Beeckman, H., 2012. Fluctuations of cambial activity in relation to precipitation result in annual rings and intra-annual growth zones of xylem and phloem in teak (Tectona grandis) in Ivory Coast. Ann. Bot. 110, 861-873. https://doi.org/10.1093/aob/mcs145.

Donato, D.C., Kauffman, J.B., Murdiyarso, D., Kurnianto, S., Stidham, M., Kanninen, M., 2011. Mangroves among the most carbon-rich forests in the tropics. Nat. Geosci. 4, 293-297. https://doi.org/10.1038/ngeo1123.

Douglass, A.E., 1941. Crossdating in dendrochronology. J. For. 39, 825-831.

Eckstein, D., Bauch, J., 1969. Beitrag zur rationalisierung eines dendrochronologischen Verfahrens und zur Analyse seiner Aussagesicherheit. Forstwiss. Cent. 88, 230-250. https://doi.org/10.1007/BF02741777.

Ellison, A.M., Mukherjee, B.B., Karim, A., 2000. Testing patterns of zonation in mangroves: scale dependence and environmental correlates in the Sundarbans of Bangladesh. J. Ecol. 88, 813-824. https://doi.org/10.1046/j.1365-2745.2000. 00500.x.

Fahn, A., 1982. Plant Anatomy, 3rd ed. Pergamon Press, Oxford 492 pp.

Fritts, H.C., 1976. Tree Rings and Climate. Academic Press, London 567 pp.

Gaspard, D.T., Venegas-González, A., Beeckman, H., Randriamalala, J.R., TomazelloFilho, M., De Ridder, M., Ramananantoandro, T., 2018. Tree ring responses to climate variability of xerophytic thickets from South Soalara, Madagascar. Dendrochronologia 49, 57-67. https://doi.org/10.1016/j.dendro.2018.02.003.

Gebrekirstos, A., Bräuning, A., Sass-Klassen, U., Mbow, C., 2014. Opportunities and applications of dendrochronology in Africa. Curr. Opin. Environ. Sustain. 6, 48-53. https://doi.org/10.1016/j.cosust.2013.10.011.

Gilman, E.L., Ellison, J., Duke, N.C., Field, C., 2008. Threats to mangroves from climate change and adaptation options: a review. Aquat. Bot. 89, 237-250. https://doi.org/ 10.1016/j.aquabot.2007.12.009.

Gričar, J., Zupančič, M., Čufar, K., Oven, P., 2007. Regular cambial activity and xylem and phloem formation in locally heated and cooled stem portions of Norway spruce. 
Wood Sci. Technol. 41, 463-475. https://doi.org/10.1007/s00226-006-0109-2.

Groenendijk, P., Sass-Klaassen, U., Bongers, F., Zuidema, P.A., 2014. Potential of tree-ring analysis in a wet tropical forest: a case study on 22 commercial tree species in Central Africa. For. Ecol. Manage. 323, 65-78. https://doi.org/10.1016/j.foreco.2014.03. 037.

Himes-Cornell, A., Pendleton, L., Atiyah, P., 2018. Valuing ecosystem services from blue forests: a systematic review of the valuation of salt marshes, sea grass beds and mangrove forests. Ecosyst. Serv. 30, 36-48. https://doi.org/10.1016/j.ecoser.2018. 01.006.

Huang, J.-G., Bergeron, Y., Berninger, F., Zhai, L., Tardif, J.C., Denneler, B., 2013. Impact of future climate on radial growth of four major boreal tree species in the eastern Canadian boreal forest. PLoS One 8, e56758. https://doi.org/10.1371/journal.pone. 0056758.

Iftekhar, M., Saenger, P., 2008. Vegetation dynamics in the Bangladesh Sundarbans mangroves: a review of forest inventories. Wetlands Ecol. Manage. 16, 291-312. https://doi.org/10.1007/s11273-007-9063-5.

Iqbal, M., 1990. The Vascular Cambium. Research Studies Press Ltd., Taunton 246 pp.

Islam, M.S.N., Gnauck, A., 2009. Threats to the Sundarbans mangrove wetland ecosystems from transboundary water allocation in the Ganges basin: a preliminary problem analysis. Int. J. Ecol. Econ. Stat. 13, 64-78.

Islam, S.N., Gnauck, A., 2011. Water salinity investigation in the Sundarbans rivers in Bangladesh. Int. J. Water 6, 74-91.

Islam, M., Rahman, M., Bräuning, A., 2018a. Growth-ring boundary anatomy and dendrochronological potential in a moist tropical forest in northeastern Bangladesh. Tree. Res. 74, 76-93. https://doi.org/10.3959/1536-1098-74.1.76.

Islam, M.M., Sunny, A.R., Hossain, M.M., Friess, D.A., 2018b. Drivers of mangrove ecosystem service change in the Sundarbans of Bangladesh. Singapore J. Trop. Geogr. 39, 244-265. https://doi.org/10.1111/sjtg.12241.

Jansen, S., Choat, B., Vinckier, S., Lens, F., Schols, P., Smets, E., 2004. Intervascular pit membranes with a torus in the wood of Ulmus (Ulmaceae) and related genera. New Phytol. 163, 51-59. https://doi.org/10.1111/j.1469-8137.2004.01097.x.

Köhl, M., Neupane, P.R., Lotfiomran, N., 2017. The impact of tree age on biomass growth and carbon accumulation capacity: a retrospective analysis using tree ring data of three tropical tree species grown in natural forests of Suriname. PLoS One 12, e0181187. https://doi.org/10.1371/journal.pone.0181187.

Larson, P.R., 1994. The Vascular Cambium: Development and Structure. Springer-Verlag, Berlin $707 \mathrm{pp}$.

Lisi, C.S., Fo, M.T., Botosso, P.C., Roig, F.A., Maria, V.R., Ferreira-Fedele, L., Voigt, A.R., 2008. Tree-ring formation, radial increment periodicity, and phenology of tree species from a seasonal semi-deciduous forest in southeast Brazil. IAWA J. 29, 189-207. https://doi.org/10.1163/22941932-90000179.

Marcati, C.R., Angyalossy, V., Evert, R.F., 2006. Seasonal variation in wood formation of cedrela fissilis (meliaceae). IAWA J. 27, 199-211. https://doi.org/10.1163/ 22941932-90000149.

Marcati, C.R., Milanez, C.R.D., Machado, S.R., 2008. Seasonal development of secondary xylem and phloem in Schizolobium parahyba (Vell.) Blake (Leguminosae: caesalpinioideae). Trees 22, 3-12. https://doi.org/10.1007/s00468-007-0173-8.

Marcati, C.R., Machado, S.R., Podadera, D.S., Lara, N.O.Td., Bosio, F., Wiedenhoeft, A.C., 2016. Cambial activity in dry and rainy season on branches from woody species growing in Brazilian Cerrado. Flora 223, 1-10. https://doi.org/10.1016/j.flora.2016. 04.008.

Martinez del Castillo, E., Prislan, P., Gričar, J., Gryc, V., Merela, M., Giagli, K., de Luis, M., Vavrčík, H., Čufar, K., 2018. Challenges for growth of beech and co-occurring conifers in a changing climate context. Dendrochronologia 52, 1-10. https://doi.org/10. 1016/j.dendro.2018.09.001.

Maxwell, J.T., Harley, G.L., Rahman, A.F., 2018. Annual growth rings in two mangrove species from the Sundarbans, Bangladesh demonstrate linkages to sea-level rise and broad-scale ocean-atmosphere variability. Wetlands 38, 1159-1170. https://doi.org/ 10.1007/s13157-018-1079-5.

Mbow, C., Chhin, S., Sambou, B., Skole, D., 2013. Potential of dendrochronology to assess annual rates of biomass productivity in savanna trees of West Africa. Dendrochronologia 31, 41-51. https://doi.org/10.1016/j.dendro.2012.06.001.

McLeod, E., Salm, R.V., 2006. Managing Mangroves for Resilience to Climate Change. 64 pp.

Menezes, M., Berger, U., Worbes, M., 2003. Annual growth rings and long-term growth patterns of mangrove trees from the Bragança peninsula, North Brazil. Wetlands Ecol. Manage. 11, 233-242. https://doi.org/10.1023/A:1025059315146.

Mirza, M.M.Q., 1998. Diversion of the Ganges water at Farakka and its effects on salinity in Bangladesh. Environ. Manage. 22, 711-722. https://doi.org/10.1007/ s002679900141.

Morel, H., Mangenet, T., Beauchêne, J., Ruelle, J., Nicolini, E., Heuret, P., Thibaut, B., 2015. Seasonal variations in phenological traits: leaf shedding and cambial activity in Parkia nitida Miq. And Parkia velutina Benoist (Fabaceae) in tropical rainforest. Trees 29, 973-984. https://doi.org/10.1007/s00468-015-1177-4.

Priya, P., Bhat, K., 1999. Influence of rainfall, irrigation and age on the growth periodicity and wood structure in teak (Tectona grandis). IAWA J. 20, 181-192. https://doi.org/ 10.1163/22941932-90000678.

Pumijumnong, N., 2013. Dendrochronology in Southeast Asia. Trees 27, 343-358. https://doi.org/10.1007/s00468-012-0775-7.

Pumijumnong, N., Buajan, S., 2013. Seasonal cambial activity of five tropical tree species in central Thailand. Trees 27, 409-417. https://doi.org/10.1007/s00468-0120794-4.

Quinn, G.P., Keough, M.J., 2002. Experimental Design and Data Analysis for Biologists. Cambridge University Press, Cambridge 537 pp.

Rahaman, S.M., Biswas, S.K., Rahaman, M.S., Ghosh, A.K., Sarder, L., Siraj, S., Islam, S.S., 2014. Seasonal nutrient distribution in the Rupsha-Passur tidal river system of the
Sundarbans mangrove forest, Bangladesh. Ecol. Process. 3, 18. https://doi.org/10. 1186/s13717-014-0018-5.

Rahman, M., Islam, R., Islam, M., 2017. Long-term growth decline in Toona ciliata in a moist tropical forest in Bangladesh: impact of global warming. Acta Oecol. Montrouge (Montrouge) 80, 8-17. https://doi.org/10.1016/j.actao.2017.02.004.

Rashid, M.E., Rahman, M.A., 2012. Updated nomenclature and taxonomic status of the plants of Bangladesh included in Hook. f., the Flora of British India: Volume-II. Bangladesh J. Plant Taxon. 19, 173-190.

Reef, R., Lovelock, C.E., 2015. Regulation of water balance in mangroves. Ann. Bot. 115, 385-395. https://doi.org/10.1093/aob/mcu174.

Rinn, F., 2003. TSAP-Win: Time Series Analysis and Presentation for Dendrochronology and Related Applications. Frank Rinn, Heidelberg.

Robert, E.M.R., Schmitz, N., Okello, J.A., Boeren, I., Beeckman, H., Koedam, N., 2011. Mangrove growth rings: fact or fiction? Trees 25, 49-58. https://doi.org/10.1007/ s00468-010-0487-9.

Robert, E.M., Jambia, A.H., Schmitz, N., De Ryck, D.J., De Mey, J., Kairo, J.G., DahdouhGuebas, F., Beeckman, H., Koedam, N., 2014. How to catch the patch? A dendrometer study of the radial increment through successive cambia in the mangrove Avicennia. Ann. Bot. 113, 741-752. https://doi.org/10.1093/aob/mcu001.

Rossi, S., Deslauriers, A., Anfodillo, T., 2006. Assessment of cambial activity and xylogenesis by microsampling tree species: an example at the Alpine timberline. IAWA J. 27, 383. https://doi.org/10.1163/22941932-90000161.

Rozendaal, D.M.A., Zuidema, P.A., 2010. Dendroecology in the tropics: a review. Trees 25, 3-16. https://doi.org/10.1007/s00468-010-0480-3.

Ruxton, G.D., 2006. The unequal variance t-test is an underused alternative to Student's ttest and the Mann-Whitney U test. Behav. Ecol. 17, 688-690.

Santini, N.S., Hua, Q., Schmitz, N., Lovelock, C.E., 2013. Radiocarbon dating and wood density chronologies of mangrove trees in arid Western Australia. PLoS One 8, e80116. https://doi.org/10.1371/journal.pone.0080116.

Sarker, S.K., Reeve, R., Thompson, J., Paul, N.K., Matthiopoulos, J., 2016. Are we failing to protect threatened mangroves in the Sundarbans world heritage ecosystem? Sci. Rep. 6. https://doi.org/10.1038/srep21234.

Sarker, S.K., Reeve, R., Paul, N.K., Matthiopoulos, J., 2019. Modelling spatial biodiversity in the world's largest mangrove ecosystem-the Bangladesh Sundarbans: a baseline for conservation. Divers. Distrib. 25, 729-742. https://doi.org/10.1111/ddi.12887.

Savva, Y., Oleksyn, J., Reich, P.B., Tjoelker, M.G., Vaganov, E.A., Modrzynski, J., 2006. Interannual growth response of Norway spruce to climate along an altitudinal gradient in the Tatra Mountains, Poland. Trees 20, 735-746. https://doi.org/10.1007/ s00468-006-0088-9.

Schindelin, J., Arganda-Carreras, I., Frise, E., Kaynig, V., Longair, M., Pietzsch, T., Preibisch, S., Rueden, C., Saalfeld, S., Schmid, B., 2012. Fiji: an open-source platform for biological-image analysis. Nat. Methods 9, 676-682. https://doi.org/10.1038/ nmeth.2019.

Schmitz, N., Verheyden, A., Beeckman, H., Kairo, J.G., Koedam, N., 2006. Influence of a salinity gradient on the vessel characters of the mangrove species Rhizophora mucronata. Ann. Bot. 98, 1321-1330. https://doi.org/10.1093/aob/mcl224.

Schmitz, N., Verheyden, A., Kairo, J.G., Beeckman, H., Koedam, N., 2007. Successive cambia development in Avicennia marina(Forssk.) Vierh. is not climatically driven in the seasonal climate at Gazi Bay, Kenya. Dendrochronologia 25, 87-96. https://doi. org/10.1016/j.dendro.2006.08.001.

Schmitz, N., Robert, E.M., Verheyden, A., Kairo, J.G., Beeckman, H., Koedam, N., 2008. A patchy growth via successive and simultaneous cambia: key to success of the most widespread mangrove species Avicennia marina? Ann. Bot. 101, 49-58. https://doi. org/10.1093/aob/mcm280.

Schöngart, j., Orthmann, b., Hennenberg, kj., Porembski, s., Worbes, m., 2006. Climate-growth relationships of tropical tree species in West Africa and their potential for climate reconstruction. Glob. Change Biol. Bioenergy 12, 1139-1150. https://doi.org/10.1111/j.1365-2486.2006.01154.x.

Siddiqi, N.A., 2001. Mangrove Forestry in Bangladesh. Institute of Forestry \& Environmental Sciences, University of Chittagong 301 pp.

Siddiqi, N.A., Islam, M.R., Khan, M.A.S., 1989. Effect of salinity on germination success in keora (Sonneratia apetala Buch.-Ham.) seeds. Bano Biggyan Patrika 18, 57-62.

Srivastava, R., Suzuki, M., 2001. More fossil woods from the Palaeogene of northern Kyushu, Japan. IAWA J. 22, 85-105. https://doi.org/10.1163/22941932-90000271.

Tomlinson, P.B., 1986. The Botany of Mangroves, 2 ed. Cambridge University Press, Cambridge 406 pp.

Trouet, V., Esper, J., Beeckman, H., 2010. Climate/growth relationships of Brachystegia spiciformis from the miombo woodland in south central Africa. Dendrochronologia 28, 161-171. https://doi.org/10.1016/j.dendro.2009.10.002.

Venugopal, N., Krishnamurthy, K.V., 1994. Seasonal pattern of cell division in the vascular cambium of some tropical timber trees. Cytologia 59, 323-332. https://doi.org/ 10.1508/cytologia.59.323.

Venugopal, N., Liangkuwang, M.G., 2007. Cambial activity and annual rhythm of xylem production of elephant apple tree (Dillenia indica Linn.) in relation to phenology and climatic factor growing in sub-tropical wet forest of northeast India. Trees 21, 101-110. https://doi.org/10.1007/s00468-006-0101-3.

Verheyden, A., Kairo, J.G., Beeckman, H., Koedam, N., 2004. Growth rings, growth ring formation and age determination in the mangrove Rhizophora mucronata. Ann. Bot. 94, 59-66. https://doi.org/10.1093/aob/mch115.

Wagner, F., Rossi, V., Aubry-Kientz, M., Bonal, D., Dalitz, H., Gliniars, R., Stahl, C., Trabucco, A., Herault, B., 2014. Pan-tropical analysis of climate effects on seasonal tree growth. PLoS One 9, e92337. https://doi.org/10.1371/journal.pone.0092337.

Wahid, S.M., Babel, M.S., Bhuiyan, A.R., 2007. Hydrologic monitoring and analysis in the Sundarbans mangrove ecosystem, Bangladesh. J. Hydrol. (Amst) 332, 381-395. https://doi.org/10.1016/j.jhydrol.2006.07.016.

Wheeler, E.A., 2011. Inside Wood - A Web Resource for Hardwood Anatomy 32. pp. 199. 
https://doi.org/10.1163/22941932-90000051.

Wigley, T.M.L., Briffa, K.R., Jones, P.D., 1984. On the average value of correlated time series, with applications in dendroclimatology and hydrometeorology. J. Climate Appl. Meteorol. 23, 201-213. https://doi.org/10.1175/1520-0450(1984) $023<0201$ :OTAVOC > 2.0.CO;2.

Woodroffe, C., 1982. Litter production and decomposition in the New Zealand mangrove, Avicennia marina var. Resinifera. New Zealand J. Mar. Freshwat. Res. 16, 179-188. https://doi.org/10.1080/00288330.1982.9515961.

Worbes, M., 1992. Occurrence of Seasonal Climate and Tree-ring Research in the Tropics,
Lundqua Report No. 34. Sweden 338-342.

Worbes, M., 1995. How to measure growth dynamics in tropical trees: a review. IAWA J. 16, 337-351. https://doi.org/10.1163/22941932-90001424.

Worbes, M., Staschel, R., Roloff, A., Junk, W., 2003. Tree ring analysis reveals age structure, dynamics and wood production of a natural forest stand in Cameroon. For. Ecol. Manage. 173, 105-123. https://doi.org/10.1016/S0378-1127(01)00814-3.

Yan, L., Guizhu, C., 2007. Physiological adaptability of three mangrove species to salt stress. Acta Ecol. Sin. 27, 2208-2214. https://doi.org/10.1016/s1872-2032(07) 60052-3. 